\title{
The Use of Grammatical Elements to Achieve Persuasion in Advertising in the Print Media in Ghana
}

\author{
Dr Richard T. Torto \\ Department of Communication Studies, University of Cape coast, Cape Coast, Ghana
}

\begin{abstract}
Advertising is a type of communication whose ultimate goal is to persuade potential customers of the good qualities of products and services. There are various strategies that advertisers employ in order to persuade their customers to take purchasing decisions. One of them is the designing of an advertisement in which the pictorial images and other graphic designs are prominent. Another persuasive technique is the use of language to transmit the advertising message. In this regard, copywriters employ language in an attractive way to achieve persuasion in advertisements. It is worth postulating that although a number of persuasive strategies are available in advertising, language is integral in the communication of information. The focus of the current study was the use of grammatical elements in the English of advertisements by copywriters in the newspapers in Ghana for persuasive effect. The qualitative research design was employed and the study was underpinned by the Standard Theory of Generative Grammar. The current study proved that copywriters in the print media in Ghana employed imperative and declarative sentences, nominal phrases, the second person personal pronoun and modifiers such as adjectives and adverbs for persuasive effect.
\end{abstract}

Keywords: Grammatical Units, Standard Theory, Advertising, Advertisement, Advertiser, Copywriter, English language, Print media, Persuasion, Communication.

DOI: $10.7176 / \mathrm{NMMC} / 85-05$

Publication date: November $30^{\text {th }} 2019$

\section{Introduction}

Advertising had been employed for commercial purpose since historic time and it had undergone transformation over the years. In ancient Greece, Babylon, Egypt and the Roman Empire, advertising took the form of images, symbols and signs on walls and shops (Moriarty, Mitchell \& Wells, 2009). This was to create the awareness about products and their places of manufacture. In ancient China, advertising was either verbal or by the use of musical instruments; later, advertising took the form of writings on signboards and posters. In the medieval period in Europe, advertising took the form of exhibition of finished products because many people could not read and write. Advertising was also like oral announcement at public places and this was to draw customers' attention. Art work on rocks and walls for advertising started in India many centuries ago (Bhatia, 2000). Advertising underwent changes during the Renaissance Period in Europe in the fifteenth and sixteenth centuries when advancement in printing gave rise to literacy. With the advent of an innovative printing technology in Asia and Europe in the second half of the fifteenth century, printing was done on a large scale and people read extensively to broaden their intellectual horizon. Information dissemination was improved and advertising was given the needed publicity in the print media (Moriarty et al, ibid). Advertising, therefore, took the form of mass communication for commercial purposes in newspapers in America and England in the seventeenth and eighteenth centuries respectively. During the period of the Industrial Revolution in the eighteenth century, which saw a rise in the production of goods, advertising in the print media in the United States (US) and Europe helped manufacturers to disseminate information about their products to prospective buyers.

Due to modern technological development and many mass media communication channels advertising has attained great heights; it forms an integral part of our world today (Cook, 1992). Advertising in modern time is a complex form of communication that aims at achieving positive responses from a targeted audience through different kinds of mass media. The print and electronic media and the Internet are employed extensively in the transmission of advertising messages today. These days, other forms of information dissemination instruments such as billboards, cell-phones, trains, aircrafts, buses, buildings, stadia and movies are employed as advertising media. Nowadays, advertisers choose the appropriate media to disseminate the advertising message. In advertising, the media are the channels or vehicles for the spread of the advertising information to the target audience. There are a number of media houses or companies that are engaged by advertisers. The media houses (newspaper corporations, radio stations, TV studios, billboard firms) across the globe have departments in charge of the sale of advertising space or air-time. The media companies provide consultancy services to advertisers in terms of the choice of channels of communication and the production of effective advertisements. These days commercial advertising is paid for by the advertisers; however, media organizations do not charge for public service advertising (Moriarty et al, 2009).

In contemporary time, another essential component of advertising is the advertising agency. Its mandate is the actual construction of advertisements. The advertising agency is able to perform this task by employing 
experts in various advertising fields. The agency in advertising is responsible for the production, dissemination or transmission of advertisements in the media. Some well established business organizations have Advertising Agency Departments that concern themselves with the business of advertising. Such companies with internal advertising agencies are able to oversee and control advertising activities. Modern advertising is characterized by a group of experts and organizations who provide supporting services to advertisers, advertising agencies and media houses in the course of advertisement production (Moriarty et al, ibid). Today, different experts work behind the scenes in the production of advertisements. Some of these experts, specialists and professionals who contribute to advertisement creation and production include: Copywriters, graphic designers, photographers, cameramen, visual artists, computer scientists, programmers, musicians, sound engineers, film directors, actors/actresses, celebrities, comedians, media consultants, marketers and researchers. Although an advertisement is made up of different components, language forms an integral part in the transmission of the message and it makes the advertising discourse memorable. In the current study, I investigated the use of grammatical units in the English of adverts by copywriters in the Ghanaian press for persuasive effect.

\section{Review of Literature}

Pigott (1996) did a comparative study on the use of British and American English in television (TV) advertising. In the study, Pigott discovered that the British advertisers employed subtle persuasive strategies in both the visual images and the words in TV advertisements. The British TV advertisers incorporated the life experiences of the UK audience, stimulated their emotions and enthusiasm and also appealed to their basic needs. According to Rothenberg (1989), the British copywriters applied features of film production to their TV advertisements and this made them highly dramatic. Rothenberg also described TV in the UK in the 1980s as creative and pleasurable. According to Pigott (1996), the dramatic genre that the British advertising agencies adopted was Burke's (1969) comedy style. This dramatic category stressed setting and characterization in the TV advertisements. By the use of complex dramatic techniques and appropriate diction, British TV advertising agencies devised advertisements that were comic and humorous and Ehrenberg (1989) described them as entertaining. Pigott (1996) postulated that the British dramatic approach to advertising was more effective than the US since it yielded more positive responses.

From Pigott's (1996) study it could be deduced that the US TV advertisements were not as dramatic, comic, humorous and entertaining as the British. According to Pigott, the US advertising on TV had a number of flaws which made advertisements less effective than the British. In the first place, the US advertising agencies were more business oriented; their ultimate goal was to sell and reap financial gains. They used direct persuasive strategies which were quite aggressive. Secondly, the US TV advertisements had multiple scenes within them and the rapid changing of these scenes disturbed the focus and memory of viewers. According to Lang (1991), the right side of the human brain influences our visual memory while the left part has an impact on the auditory or verbal memory. Lang posits that scene changes on TV affects memory negatively. Due to the fast changing of scenes in the US TV advertisements, the various segments of the advertisements appeared on the screen for only a few seconds. As a result, the changes in the variety of visual images in the US TV advertisement interfered with the visual memory of viewers. On the other hand, the British TV advertisements did not undergo rapid scene changes and the advertisements stayed longer on the screen for the consumption of the audience. A third flaw in the US TV advertising was that US advertisers were influenced by the musical video technique on TV; however, this style was too fast for advertising. According to Pigott (1996), the musical videos appealed more to the sense of hearing of viewers than their sense of sight, while TV advertisements normally appealed more to the audience sense of sight than hearing. Moyer (1989) supports Pigott's (1996) claim: After analyzing political campaign advertisements on TV in the US, Moyer (1989) concluded that visual images, almost invariably, are more attractive than the words. Moyer reported that in a presidential campaign advertisement on TV in the US, derogatory words against an opponent were rendered ineffective by visual images.

Pigott's (1996) study showed that in the last decade of the twentieth century, British TV advertisements were more effective than the US. This was because the former was more memorable, humorous and entertaining. Pigott agreed with Ogilvy (1983) who claimed that the British advertising industry was occupying the first position in the world. Pigott (1996) presented the way forward for the two advertising giants in the world and this was the collaboration between the US and British advertising agencies. For instance, the American advertisers were emulating the British dramatic techniques in TV advertising. The British advertising agencies on their part bought the best advertising agencies from the US. Pigott (1996) researched into the effectiveness of the English used in TV advertisements in terms of entertainment, humor and drama; however, what was yet to be known was the persuasive effect which was the ultimate goal of advertising; the current study filled this knowledge gap.

Another major research on the use of English in advertising that is worth reviewing was Gerritsen, Nickerson, Hooft, Meurs, Hubert, Nederstigt, Starren, \& Crijns (2010). This was a study on the effect of the use of English in product advertisements in five Western European countries (Germany, Spain, France, Netherlands 
and Belgium) where English is spoken as a second language. The review of the literature on the use of English in advertising in Western Europe showed that English was included in a large number of advertisements than any foreign language (Bhatia, 1992; Martin, 2002; Piller, 2003). According to Gerritsen et al (2010), the reasons why advertisers employed English in product advertisements in the five non-Anglophone Western European countries under review were because they (advertisers) assumed that their audience understood English and because English promoted the image and price of the advertized product. Gerritsen et al (2010) investigated the extent to which consumers comprehended the advertized message communicated in English and the effect of the use of English in advertisements on the image and price of the advertized products. From the literature, there were other reasons advanced by researchers, from a broad perspective, on the frequent use of English in European advertisements. One reason was the standardization approach in which English was incorporated in all product advertisements in Europe (Levitt, 1983; Onkvisit \& Shaw, 1987). Other scholars were also of the view that uniformity in advertising would work in favor of the globalization of markets (Zou \& Cavusgu, 2002). Another reason postulated for the use of English in European advertisements was because certain essential products were manufactured in America or Britain and it was more semantically prudent to describe the products in English (Friedrich, 2002; Takahashi, 1990) than in any of the native languages in Europe. The third reason why English was employed in European advertisements was due to its global nature (Bailey \& Gorlach, 1986; Cystal 2003, 2004). Advertising Agencies therefore assumed that everyone in Europe understood English. Other researchers such as Piller (2003), Kelly-Holmes (2005), Takahashi, (1990) and Ustinova and Bhatia (2005) posited that the use of English in advertisements in Europe uplifted the image of a product. According to these researchers, English was associated with modernity, it was cosmopolitan, it was prestigious and it influenced the price of an advertized product.

Although many studies (Martin, 2002; Piller, 2001; Gerritsen et al., 2000; Gerritsen et al., 2007) had showed that a large number of advertisements in Western Europe contained English, not much was known about its effects. Gerritsen et al (2010) filled this knowledge gap in their investigation on the effect of English on educated women and the impact English had on the image and price of advertized products. The results of Gerritsen et al (2010) revealed that about forty percent of the English texts of the advertisements were not understood by the consumers. This implied that the inclusion of English in the advertisements of nonAnglophone Western Europe would not yield the requisite results since the majority of consumers might not understand the advertising message fully. The results of the study also proved that the use of English in product advertisements did not have any significant impact on the image and price of the advertized products. There was a parallel connection between Gerritsen et al (2010) and the current study since both focused on the English used in product advertisements. However, the difference that existed between Gerritsen et al (2010) and the current study was that while Gerritsen et al (2010) researched into the extent of comprehension of the English employed in the advertisement in the Western part of Europe, the current study concentrated on the use of grammatical elements in the English employed in advertisements in newspapers in Ghana for persuasive effect. This was the knowledge gap that the current study filled in Gerritsen et al (2010).

In the West Africa sub-region, Adamu (2009) analyzed the English used in adverts in the print media in Nigeria. The study showed the use of intensification and downplaying as persuasive strategies in adverts in newspapers and magazines in Nigeria. The study revealed the use of visual images, graphic designs, signs and symbols in Nigerian adverts. Adamu (2009) discovered the use of Nigerian cultural elements in adverts for persuasive effects. Advertisers in Nigeria incorporated elements that Nigerians could identify with: kola-nut, proverbs, greetings and traditional wear. The use of adjectives and adverbs, simple and colloquial sentences, imperative constructions, figurative expressions formed part of the English of advertising in Nigerian adverts. Adamu's findings served to illustrate what was already known on the use of English in advertising in Nigeria. What still needed to be known was the use of grammatical elements in the English of advertisements to achieve persuasion in the advertising discourse. In the Ghanaian context, Duah (2007) selected samples of English and Akan (a Ghanaian language) adverts from print (Graphic \& Times) and electronic media (Peace FM, Joy FM, Adom FM, Gold FM and Happy FM) in Ghana, and he investigated the discourse strategies employed in the advertisements for persuasive effect. The study revealed that one of the strategies that advertisers used to persuade their audience was the use of language forms that helped them to identify with their audience. According to him, the advertiser used expressions, address forms and words which were similar to or the same as those used by the audience. By this strategy, the copywriter tried to establish rapport with certain classes of people in society. This enticed the audience to the copywriter's message and elicited from them positive responses leading to purchasing decisions on the advertized products or services. Duah's work also revealed that there was a general thinking in Ghana which was that products from the developed world were superior to those from developing nations. Therefore, if a product was said to have come from the USA, for instance, there was a tendency for people to associate the product with attributes like good quality and originality. In this regard, the country of origin of a product was enough motivation for people to prefer it to other similar ones manufactured in Ghana. While the current author did a purely linguistic study, Duah (2007) focused on the discourse strategies 
that advertisers used and he demonstrated how elements in the Ghanaian culture were exploited by advertisers to persuade their audience.

\section{Theoretical Framework}

The current study was based on the Standard Theory of Generative Grammar (hereafter, ST) which was presented in Chomsky (1965). According to ST, a grammar of human language consists of a number of interactional segments: lexis, syntax, semantics, and phonology. For an expression to be meaningful, the grammar provides a structure which starts with a member of the highest grammatical unit (The sentence) and ends with a semantic structure (representing meaning) and a phonological structure (representing expression). As the highest syntactic structure, the sentence consists of all the grammatical units below it: the clause, phrase, word and morpheme. The construction of a meaningful expression in ST begins with the phrase-structure (The base) which is part of other grammatical units such as the clause and the sentence which are at the deep structure level. The semantics of a syntactic structure is the meaning that is communicated by the combination of the lexical items and this according to Chomsky is at the level of transformational structure where sentences of varied status are composed. The possible combinations of sentences at the transformational structure stage moves the grammar to the level of surface structure where the user is able to use the language to express their thoughts, desires, feelings and actions. Langendeon (1998) contributes to ST in his definition of grammar as a complete analysis of the lexicon, morphology and syntax of a language.

The Standard Theory of Generative Grammar by Chomsky (1965) had been employed in many researches involving language. Barman (2012) used the theory in his research article on the philosophy of language. Chomsky's grammatical theory continued the process of analytical philosophy which focused on language in its investigation. According to Barman (2012), Chomsky was one of the most prominent linguists of the second half of the twentieth century and he still makes an impact in the field of theoretical linguistics. For Barman, Chomsky had made a radical change in Linguistics owing to his theory of Transformational Generative Grammar (TGG) in which he highlighted the cognitive mechanisms of generating sentential structures with the use of our internal knowledge of grammar. Chomsky's contribution in the area of syntax had gone a long way to highly influence linguistic philosophers. From Barman's (2012) perspective, Chomsky employed logic and mathematics in his linguistic analysis which yielded a unique kind of language. In the process of theorizing in language, Chomsky created rules that were capable of generating all the possible combinations of lexical units in the formation of grammatical sentences of human language.

Chomsky's Standard Theory influenced the philosophy of many linguists; notable among them was Smith (1999). According to him, Chomsky's grammatical theory was a watershed in the history of linguistics. For Smith, Chomsky revolutionized linguistic philosophy, where language was pivotal in the process of theorization. Lycan (2008) observed that Chomsky's influence in language development had resulted in immense contribution by philosophers of language to grammar, syntax and theoretical linguistics. D'Agostino (1986) analyzed Chomsky's philosophical linguistic doctrines in detail. He highlighted Chomsky's philosophical ideas in linguistics: Intellectualism, individualism and rationalism. He went on to show that these philosophies went a long way to infiltrate the linguistic world, posed a challenge to existing theories and to create new channels of knowledge. Chomsky's work portrayed great knowledge in linguistics and had implications for modern psychology, philosophy, science, advertising and other disciplines. Chomsky's Standard Theory of Generative Grammar could be applied to all languages, universally. This linguistic theory was employed in the current study since, like the English employed in advertising, the Standard Theory of Generative Grammar was about a grammar of human language, which consisted of a number of interactional segments: lexis, syntax, semantics and phonology.

\section{Methodology \\ 4.1 Research Design}

The current study employed the qualitative research design due to its subjective and interpretative nature. It is worth stating that there are a number of approaches or methods to qualitative research. However, Leedy and Ormrod (2001) recommend the following five: case study, grounded theory, ethnography, phenomenology and content analysis. Creswell (2003) describes how these approaches meet different research needs. For example, case study and grounded theory methods are applied to researches into human activities and situations while ethnographic research analyzes the broad cultural behavior of individuals or groups. Narrative and phenomenological research can also be used to study individuals. The aspect of qualitative research that concerned the present study was the assumption made by Crotty (1998) that qualitative research is largely subjective; the investigator derives meaning from his interpretation of the data collected. Qualitative researchers collect data themselves through observation, interview and examination of documents. According to Creswell (2009), qualitative researchers make interpretations of what they observe, hear and understand; therefore, given the interpretive nature of the current study, the qualitative research design was deemed relevant. 


\subsection{Sampling}

The nature of qualitative research is such that the researcher is able to purposefully select participants, sites, documents and other research materials which will enable him or her to conceptualize the research problem and questions (Creswell, 2009). Given the qualitative nature of the current research, a purposive-sampling technique was employed in the process of data collection and this enabled the researcher to concentrate on specific features of the corpus that suited his research interest. The choice of purposive sampling for the present study was influenced by Gledhill, Abbey and Schweitzer (2008) who postulate that purposive sampling is more often chosen by many researchers in gathering data for qualitative study and by Palys (2008) who concludes that the purposive sampling method is closely related to qualitative research. Teddlie and Yu (2007) also describe purposive sampling as qualitative and purposeful.

\section{Data Analysis and Discussion}

The findings from the current study indicated that the grammar employed by copywriters in the English of the advertisements in Ghana is underpinned by Chomsky's Standard Theory of Generative grammar. Owing to the fact that the target audience were educated Ghanaians, the copywriters capitalized on the internal knowledge of English of the audience to communicate their advertising message. The copywriters employed the grammatical units such as words, phrases, clauses and sentences in the transmission of information. The advertising texts corpus revealed various grammatical thematic trends. In the ensuing section, I analyze the texts data and discuss the findings.

Text 1

Egg-cite

Your meals

Eat eggs, grow well

Did you know...

Eggs are high in quality animal protein and contain all the essential amino acids that humans need.

Eat responsibly.

(Daily Graphic, Thursday, March 2, 2017, P. 35)

The text above begins with the structure Egg-cite your meals which grabs the attention of the reader from the outset. The copywriter has coined a new word with egg, the advertised product. The coined word egg-cite resembles the English word excite. The copywriter did this on purpose in order to draw the reader's attention to the advertised product.

The imperative sentence egg-cite your meals has an implied subject who is the reader of the text. The copywriter addresses the reader directly and this produces a personal effect. By the imperative sentence, the copywriter is urging the reader to add eggs to their food in order to enjoy the good taste. The next imperative sentence in the text is short in structure: Eat eggs. It is telling the reader, in an assertive way, to consume eggs in order to benefit from its taste and nutritional value. The imperative sentence eat eggs attracts attention to itself because of its short structure. Due to its short nature, it is easy to read and it is also memorable. Another imperative sentence in the text is Grow well. This also has an implied subject who is the person the sentence is speaking to directly. The copywriter is talking to the reader about the ultimate benefit of eating eggs and he does this in an aggressive manner. This style of communicating with the audience in a short imperative sentence enables the copywriter to be concise in the presentation of his message.

In the middle of the text above, the copywriter reinforces his message on eggs consumption by creating a rhetorical question which does not require an answer from the audience as the answer is obvious: Did you know...Eggs are high in quality animal protein and contain all the essential amino acids that humans need. This rhetorical question goes a long way to compel the audience to accept the copywriter's views on the properties of eggs. The text ends with another imperative sentence Eat responsibly which also speaks to the reader directly. The copywriter advises the reader to consume eggs in moderation to avoid any negative consequences like obesity and cholesterol. The copywriter ends with an imperative sentence since it will enable him to reach a mass audience. With the imperative sentence communication is instantaneous and quick.

\section{Text 2}

We focus on the best

We have a long tradition of bringing you the best products and services. Now come for one of the world's finest; Mobil Motor Oil Available at selected Allied Service Stations.

Mobil Lubricants are recommended by top automobile manufacturers.

Your vehicles last longer and perform better with Mobil Lubricants.

(Daily Graphic, Thursday, March 30, 2017, P. 37)

The text begins with a declarative sentence we focus on the best which is simply making a statement of fact. This sentence is short; it is attractive, straight forward, readable and memorable. This simple declarative 
sentence communicates instantly and quickly. The next sentence is also declarative: We have a long tradition of bringing you the best products and services. The sentence is making an emphatic statement. It is simple and understandable. The reader is able to decode the message easily. In order to speak to the reader more directly, the copywriter constructs an imperative sentence: Now come for one of the world's finest; Mobil Motor Oil available at selected Allied Service Stations. This sentence has a personal effect on the reader; it attracts the attention of the reader to the advertised product Mobile Motor Oil. The imperative sentence is urging the reader to take a purchasing decision on the advertised product. The sentence places the reader in a position where their choice is limited to the Mobil Motor Oil. The next declarative sentence Mobil Lubricants are recommended by top automobile manufacturers makes a general statement about the advertised product. This sentence is simple and comprehensible. The copywriter presents the English in a clear and literal manner. The sentence is easy to read and it facilitates recall. The last sentence of the text is also declarative: Your vehicles last longer and perform better with Mobil lubricants. The copywriter addresses every reader personally and establishes a friendly relationship with them. The copywriter, by this strategy, engages the reader and draws their attention to the advertising message.

Text 3

Arrive in extreme comfort in the Nissan Urvan and Civilian buses. Built to make you cherish your long journeys. Enjoy the spacious legroom, comfortable seats and advanced features

Comfortable interior

Superb fuel economy

Smooth riding

(Daily Graphic, Wednesday, May 17, 2017, P. 21)

In this text, the copywriter is advertising two vehicles: The Nissan Urvan and Civilian buses. The copywriter has used series of adjectives to modify the nouns in the text. Below are examples from the text:
Extreme comfort
Long journeys
Spacious legroom
Comfortable seats
Advanced features
Comfortable interior
Superb fuel economy
Smooth riding

The adjectives are describing the nouns that they modify and this creates a word picture about the features and attributes of the two advertised vehicles. The adjectives enable the copywriter to unveil the exceptional qualities of the Nissan Urvan and the Civilian buses. This makes the audience develop positive attitudes towards the two vehicles.

\section{Text 4}

Crompton Greaves heavy Duty Electric Motors

Fully copper wound \& energy efficient. Used in Agro Processing Mills, cement, plastic and other industries, block making, vibrators, mixers, etc.

Extremely robust and long lasting

(Daily Graphic, Wednesday, August 9, 2017, P. 3)

From the text, the phrase fully copper wound demonstrates the copywriter's use of the adverb fully which is modifying the verb wound. The adverb attaches additional information to the manner in which the action of the verb was done. This creates an image in the reader's mind and makes them imagine an experience with the advertized product.

In the phrase extremely robust the copywriter also employs an adverb to complement a particular quality of the advertised product. The adverb extremely is modifying the adjective robust and it is adding more information about the degree or extent to which the electric motors that have been advertised are efficient. The adverb in the above adjectival phrase contributes to the description of the advertised product by creating a picture in the reader's mind. It also makes the reader feel a certain way about the electric motors leading to purchasing decisions. The copywriter also makes use of series of adjectives which paint a word picture about the advertised products. The following are the instances of the copywriter's use of adjectives in the above text:

\section{Heavy duty \\ Energy efficient \\ Long lasting \\ Extremely robust}

The adjectives in the above phrases are: heavy, efficient, long, lasting, robust. These adjectives provide extra information about the advertised product and they also portray various qualities of the electric motors. The adjectives reinforce the reader's positive attitude towards the advertised products. Being picturesque in nature, 
they create attractive images of the electric motors. The adjectives add emphasis to the advertising text message and make it memorable.

\section{Text 5}

Hyundai Truck \& Bus

New thinking

New possibilities

Ready stock

Genuine parts

After sales services

Dedicated \& competent team

Free specialist Driver Training Services

(Daily Graphic, Tuesday, May 23, 2017, P. 31)

In the above text, the copywriter uses nominal phrases to deliver the advertising message. Each phrase consists of a pre-modifier and a noun as the headword. The first line of the text in which the copywriter presents the advertised products is a nominal phrase that has a pre-modifier Hyundai which is the name of the advertiser. There are two advertised products: Hyundai Truck and Hyundai Bus. Lines two and three of the text New Thinking, New Possibilities have the adjective new functioning as the pre-modifier of the noun heads thinking and possibilities. Lines four and five Ready stock and Genuine parts have the adjectives ready and genuine premodifying the noun heads stock and parts. These nominal phrases are short in structure. The copywriter uses them because they can be read easily. The nominal phrases are concise and they inform in a quick way. The sixth line after sales Services consists of a pre-modifier, after sales, and the noun head services. Line seven dedicated and competent team comprises a coordinated pre-modifier dedicated and competent and a headword team. The last line free specialist driver training services has four pre-modifiers of the noun head services. The copywriter uses nominal phrases because they attract the attention of the audience to the advertised products. The nominal phrases enable the copywriter to present the advertising message in a brief and concise manner for easy communication.

\section{Text 6}

The new Kia Cerato 2017

Add a dose of extraordinary to your life

Perhaps you never thought innovation, technical excellence and exceptional style could all come together in an affordable passenger car. But finally, they do. Let the new Cerato take you places you've only imagined.

(Daily Graphic, Thursday, July 27, 2017, P. 19)

The copywriter introduces the text with the name of the advertized car: The new Kia Cerato, 2017 model. This is followed by an imperative sentence add a dose of extraordinary to your life which is speaking directly to the reader. The statement has a personal effect on the audience and makes them have a positive attitude towards the advertized car. The personal contact that has been established makes the audience feel special which implies that the advertising message was created for their attention. It can be concluded that the audience get attracted to the car because they have been personally addressed. Having grabbed the attention of the audience from the outset, the copywriter continues to talk to them in a friendly manner: Perhaps you never thought innovation, technical excellence and exceptional style could all come together in an affordable passenger car. But finally, they do. The copywriter makes the statements interactive by the use of the second person pronoun. This makes the audience feel personally involved in the advertising message. The statements engage the audience in a personal way and appeal to their thinking. Having presented an outline of the unique attributes of the Kia Cerato car and assured the audience of its affordability, the copywriter addresses the audience directly in the final statement of the text: Let the new Cerato take you places you've only imagined. The copywriter speaks to the audience in an assertive manner about the multi-purpose nature of the new Kia Cerato.

\section{Conclusion}

Language has an immense influence on human beings and their behavior. In the current study, the English language was employed in advertisements for the purpose of transmitting persuasive messages to consumers. The analysis of the advertising texts revealed that copywriters employed grammatical elements in the English of advertisements in the newspapers in Ghana to persuade their audience. The grammatical elements that were employed in the texts by copywriters for persuasive effect were: Imperative and declarative sentences, adjectives, adverbs, nominal phrases and the second person personal pronoun. The imperative sentences addressed the reader in an assertive or aggressive way by urging and encouraging them to act on the advertising textual message; the imperative sentences generally influenced the behavior of the readers. The declarative sentences persuaded the audience by making emphatic statements that were clear, literal and understandable. They were attractive, readable, concise, and they communicated quickly and with impact. The copywriters employed series of adjectives which described the nouns they modified. The adjectives enabled the copywriters to present the 
exceptional qualities of the advertised products and this drew the attention of the audience. The adverbs employed by the copywriters added more information about the verbs and the adjectives. They persuaded by creating an image in the mind of the reader about the action of the verb or the attribute of the adjective. The nominal phrases functioned as descriptive elements and they painted various word pictures in the mind of the reader with respect to the features, qualities and properties of the advertised products. The nominal phrases were concise in nature and they communicated instantly and with impact. The use of the second person pronoun enabled the copywriters to speak to the audience directly about the qualities and features of the advertised products. This had a personal effect on the audience since they had been addressed, individually. The use of the second person pronoun attracted the attention of the potential customers to the advertised products and made the advertising discourse interactive.

\section{REFERENCES}

Adamu, A. (2009). Language of Adevrtisement as a Persuasive Tool in Some Nigerian Newspapers. Unpublished M. A. Thesis, University of Ghana, Legon.

Bailey, R. W., \& Gorlach, M. (1986). English as a World Language. Ann Arbor: The University of Michigan Press.

Barman, B. (2012)."The Linguistic Philosophy of Noam Chomsky". Philosophy of Progress: Vol. LI-LII, pp. v5lil-2.17681.

Bhatia, T. K. (2000). Advertising in Rural India: Language, Marketing Communication and Consumerism. Tokyo: Institute for the Study of language and Cultures of Asia and Africa, Tokyo University of Foreign Studies.

Bhatia, T. K. (1992). "Discourse Functions and Pragmatics of mixing: Advertising across Cultures," World Englishes, 11, 195-215.

Burke, K. (1969). The Rhetoric of Motives. Berkely: University of California Press.

Chomsky, N. (1965). Aspects of the Theory of Syntax. Cambridge, M. A: MIT Press.

Cook, G. (1992). The Discourse of Advertising. London and New York: Routledge.

Creswell, W. J. (2003). Research Design: Qualitative, Qantitative and Mixed Methods Approaches (2 ${ }^{\text {nd }}$ ed.). Thousand Oaks, CA: SAGE Publications.

Creswell, W. J. (2009). Research Design: Qualitative, Qantitative and Mixed Methods Approaches (3rd ed.). Thousand Oaks, CA: SAGE Publications.

Crotty, M. (1998). The Foundations of Social Research: Meaning and Perspective in the Research Process. London: Sage.

Crystal, D. (2003). English as a Global Language. Cambridge: Cambridge University.

Crystal, D. (2004). The Stories of English. London: Penguin.

D’Agostino, F. (1986). Chomsky's System of Ideas. Oxford: Oxford University Press.

Duah, I. (2007). Advertising as persuasive Discourse: A Linguistic Analysis of Advertisements in Ghana. Unpublished Mphil Thesis, University of Cape Coast.

Ehrenberg, A. (1989). "Advertising.” The New York Times. April 14, D: 16.

Friedrich, P. (2002). "English in Advertising and Brand Naming: Sociolinguistic Considerations and the Case of Brazil," English Today: The International Review of the English Language, 18, 21-28.

Gerristen, M. Nickerson, C. Van De Brandt, C., Crijns, R., Dominguez, N., Van Meurs, F., \& Nederstgt, U. (2007). English in Print Advertising in Germany, Spain and the Netherlands: Frequency of Occurrence, Comprehensibility and the Effect on Corporate Image. In G. Garzone \& C. IIie (eds.), The Role of English in Institutional and Business Settings (Pp. 79-98). Berlin: Peter Lang.

Gerristen, M., Korzilius, H., Van Meurs, F., \& Gijsbers, I. (2000). "English in Dutch Commercials: Not Understood and not Appreciated," Journal of Advertising Research, 40, 17-36.

Gerristen, M., Nickerson, C., Hooft, V. F., Meurs, V. F., Hubert, K., Nederstigt, U., Starren, M., \& Crijns, R. (2010). "English in Product Advertisements in Non-English-Speaking Countries in Western Europe: Product Image and Comprehension of the Text," Journal of Global Marketing, 23, 349-365.

Gledhill, S. E., Abbey, J.A., \& Schweitzer, R. (2008). "Sampling Methods Methodological Issues involved in the recruitment of Older People into a Study of Sexuality," The Australian Journal of Advanced Nursing, 26, (1), 84-94.

Kelly-Holmes, H. (2005). Advertising as Multilingual Communication. Basingstoke: Palgrave Macmillan.

Lang, A. (1991). "Emotion, Formal Features, and Memory for Televised Political Advertisements," Television and Political Advertising. Vol. 1: Psychology Process. Edited by Frank Biocca. Hove and London: Lawrence Erlbaum Associates, Publishers.

Langendoen, T.D. (1998). "Linguistic Theory". A Companion to Cognitive Science. Bechtel, W. \& Graham, G. (Eds.). Oxford: Blackwell, pp. 235-244.

Leedy, P., \& Ormrod, J. (2001). Practical Research: Planning and Design (7 $7^{\text {th }}$ ed.). Upper Saddle River, N. J: 
Merrill Prentice hall. Thousand Oaks: SAGE Publications.

Levitt, T. (1983). "The Globalization of Markets," Harvard Business Review, 61(3), 92-102.

Lycan, W. G. (2008). Philosophy of Language: A Contemporary Introduction (Second edition). New York: Routledge.

Martin, E. (2002). "Mixing English in French Advertising," World Englishes, 21(3), 375-402.

Moriarty, S., Mitchell, N., \& Wells, W. (2009). Advertising: Principles and Practice (eighth edition). New Jersey: Pearson Education, Inc.

Moyer, B. (1989). “The Public Mind: Illusions of the News.” PSB Video. Alvin H. Permulter, Inc. And Public Affairs Television, Inc. New York: New York.

Ogilvy, D. (1983). Ogilvy on Advertising. New York: Crown Publishers Inc.

Onkvisit, S., \& Shaw, J. J. (1987). "Standardized International Advertising: A Review and Critical evaluation of the Theoretical and Empirical Evidence," The Columbia Journal of Business, 22(3), 43-55.

Palys, T. (2008). Purposive Sampling. In L. M. Given (Ed.). The sage Encyclopedia of Qualitative Research Methods. (Vol. 2). Sage: Los Angeles, pp. 697-8.

Pigott, M. B. (1996). "The English of Advertising: Differences in the British and American Languages of Television Advertising," Revista de Lenguas Para Fines Especificos, 3, 247-254.

Piller, I. (2001). "Identity Construction in Multilingual Advertising," Language in Society, 30, 153-186.

Piller, I. (2003). "Advertising as a Site of Language Contact," Annual Review of Applied Linguistics, 23, 170183.

Rothenberg, R. (1989). “Advertising”. The New York Times. April 14, D:16.

Smith, N. (1999). Chomsky: Ideas and Ideals. Cambridge: Cambridge University Press.

Takahashi, K. (1990). "A Sociolinguistic Analysis of English Borrowings in Japanese Advertising Texts," World Englishes, 9, 327-341.

Takahashi, K. (1990). "English Elements in Japanese Advertising," English Today, 22: 45-46.

Teddlie, C., \& Yu, F. (2007). Mixed Methods Sampling: A Typology with Examples. Journal of Mixed Methods Research, Vol. 1, 77-100.

Ustinova, I. P., \& Bhatia, T. K. (2005). "Convergence of English in Russian TV Commercials," World Englishes 24(4), 495-508.

Zou, S., \& Cavusgu, S. T. (2002). "The GMS: A Broad Conceptualization of Global Marketing Strategy and its Effect on Firm Performance," Journal of Marketing, 66, 40-56. 


\section{APPENDIX}

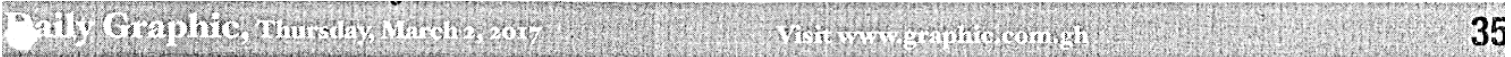

\section{EGG-CITE YOUR MEALS}

EAT EGGS, GROW WELL

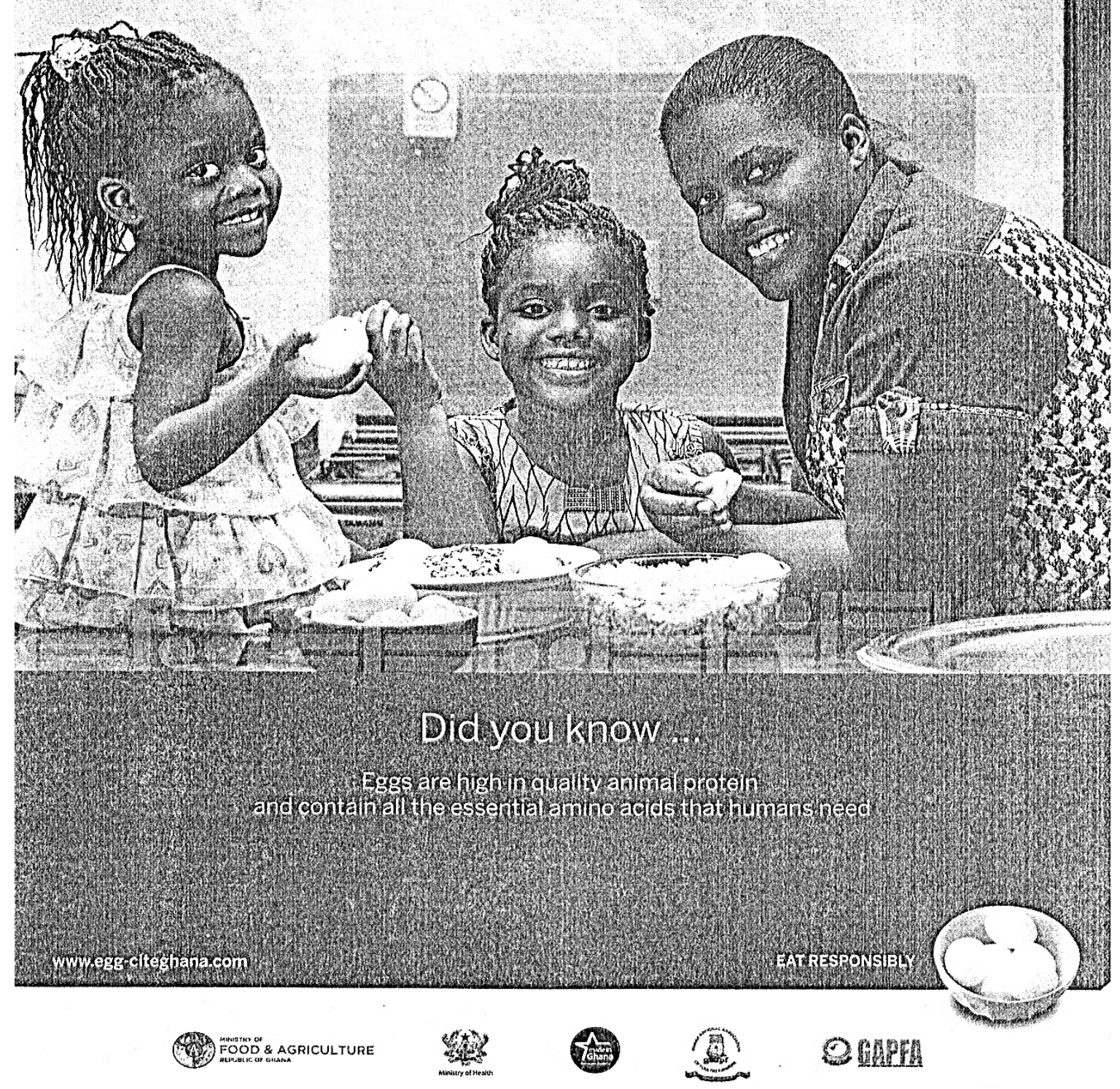




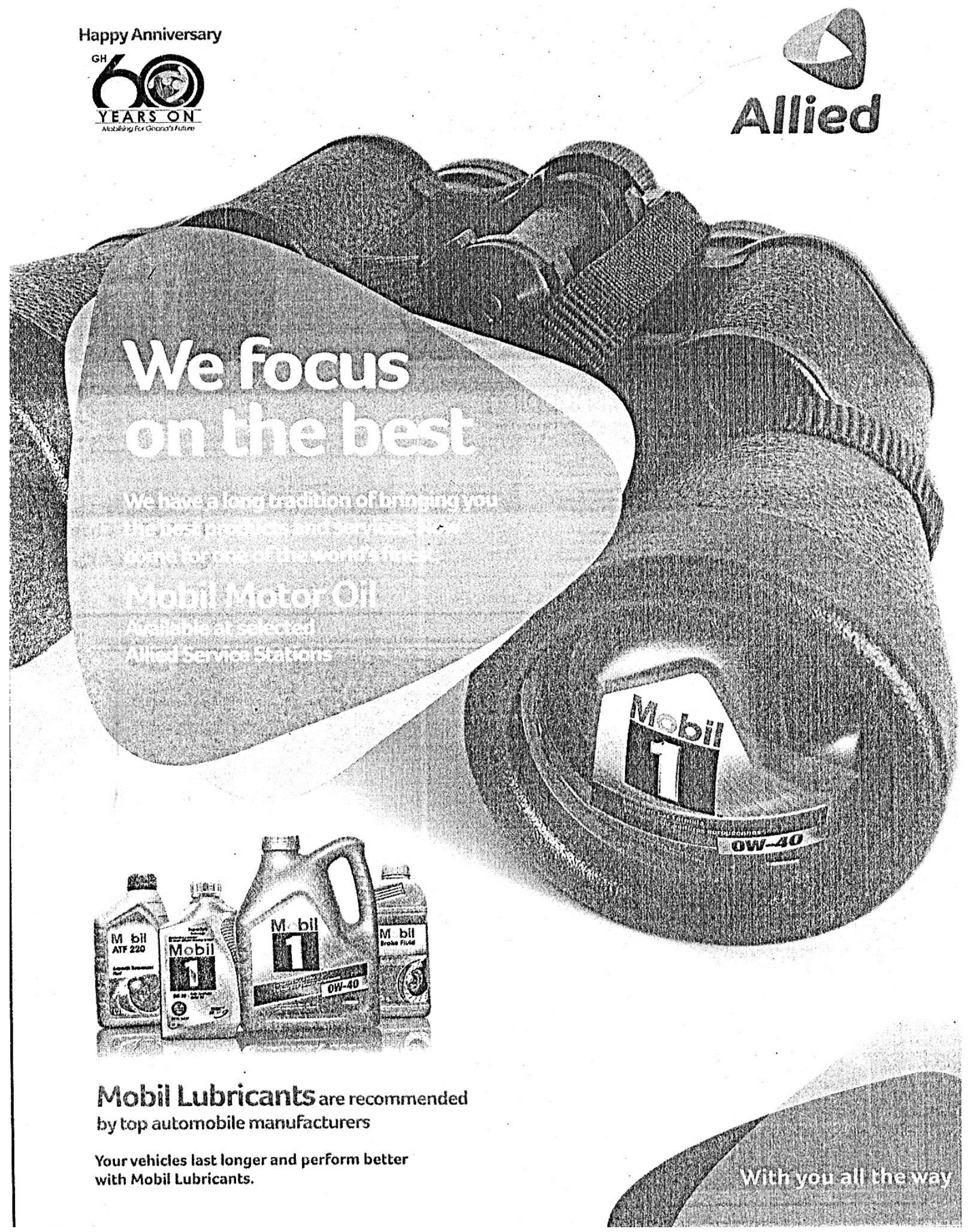


Daily Graphic, Wednesday, May 17, 2017.
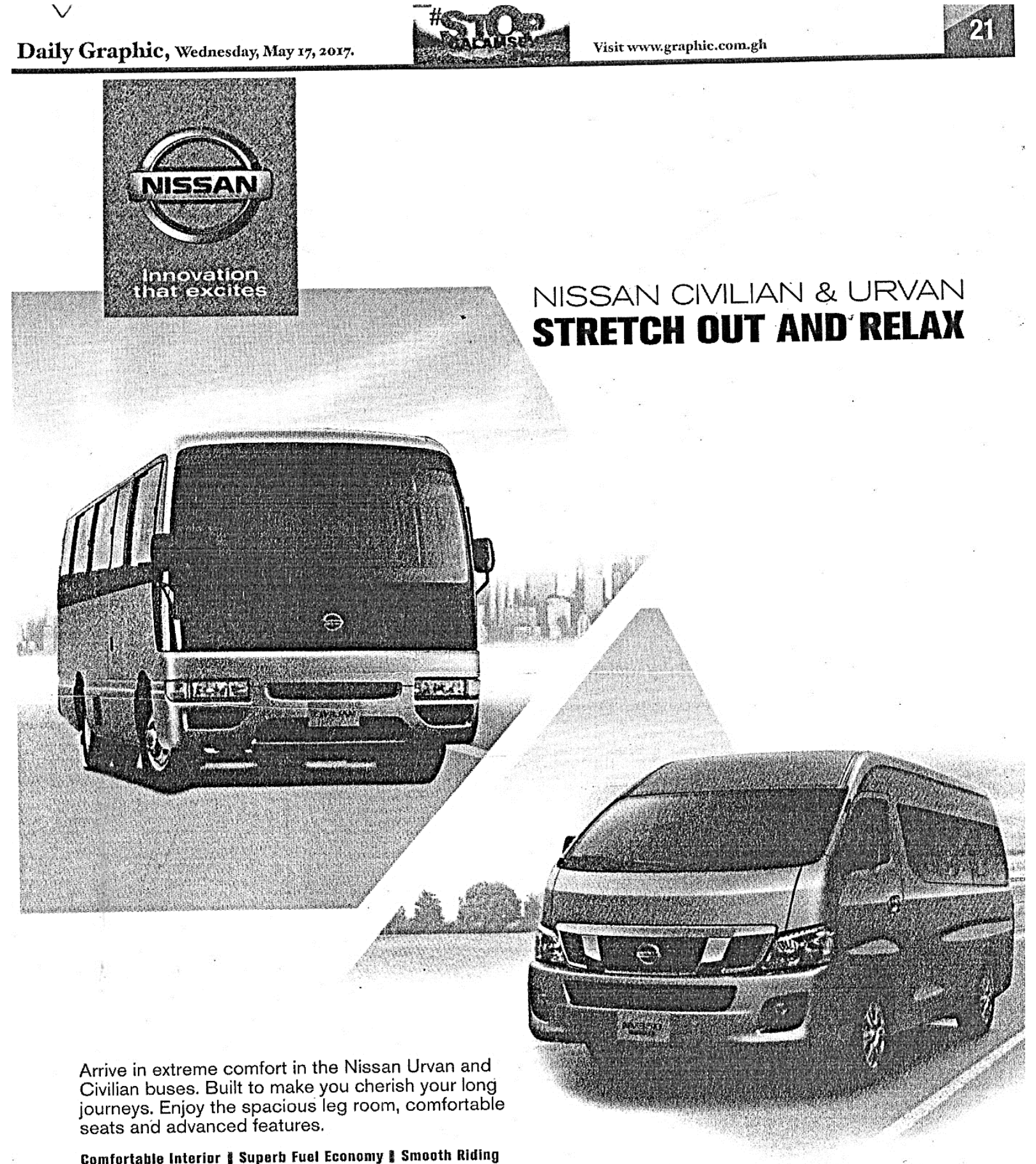

Comfortable Interior ISuperb Fuel Econonly | Smooth Riding

Available at Japan Motors

IAPAN MOTORS TRD. CO. LTD.

\section{STRETCH OUT AND RELAX}

HOT LINE: 0244338393

* Accra: 0302682220 o Silver Star Tower: 0302 768849-51

- Tema: 0303204169 Kumasi: 0322030200

Takoradi: 0312031110 e Tamale: 0372022125

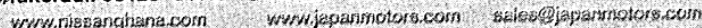

C) JapanMotorsgh

6 Japan Motors Nissan Ghana 


\section{- Admissions to reduce}

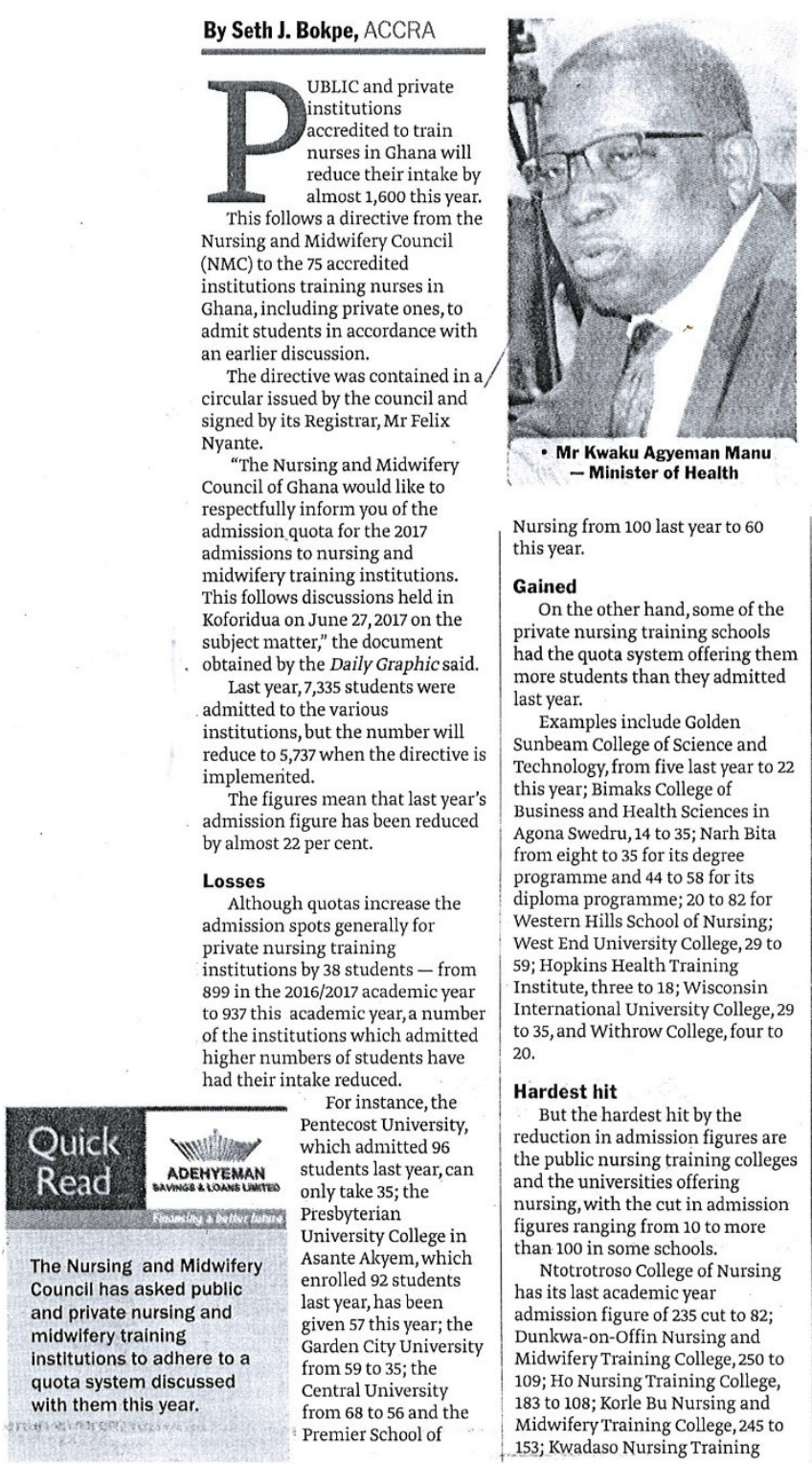

College, 254 to 152; Tamale Nursing Training College, 210 to 111 , and Keta Nursing and Midwife Others are Cape Coast Nursin raining College, 229 to 91 ; the University of Cape Coast, 100 to 75; University for Development 75; University for Development
Studies, 123 to 97 , and University of Health and Allied Sciences, 125 to (ealth

However, four of the colleges in However, four of the colleg Wa, Kwapong, Damongo and 48 students on their last year admissions.

Unhappy private institutions A source at one of the private nursing training institutions that spoke with the Daily Graphic on condition of anonymity said the decision to allocate quotas to the private institutions, especially, was wrong, as it amounted to interference that could affect the private sector's investment in education.

It said currently the accredited private nursing training institutions invested between $\mathrm{GH} \$ 3$ million and $\mathrm{GH} 44$ million in laboratory equipment and othe training aids for their nursing students and pay lecturers between $\mathrm{GH} ₫ 3,000$ and $\mathrm{GH} \oplus 8,000$.

"You are taking all this cost and they are asking you to admit a limited number of students. This no control in an educational sector where the government does not support you.This is a democratic era and they should allow private investors to run their businesses," it said.

The source said the situation could affect international students admitted by the private institution because "without the NMC 'coating" them, we cannot graduate them".

In recent times, there has been a lot of agitation by nurses trained in both public and private institutions for the government to provide them with jobs.

However, the source said it was ot all students from the priva training institutions who were absorbed into the public health system, arguing that "some of them complete and go abroad, others join private health facilities, while

- Continued on page 23
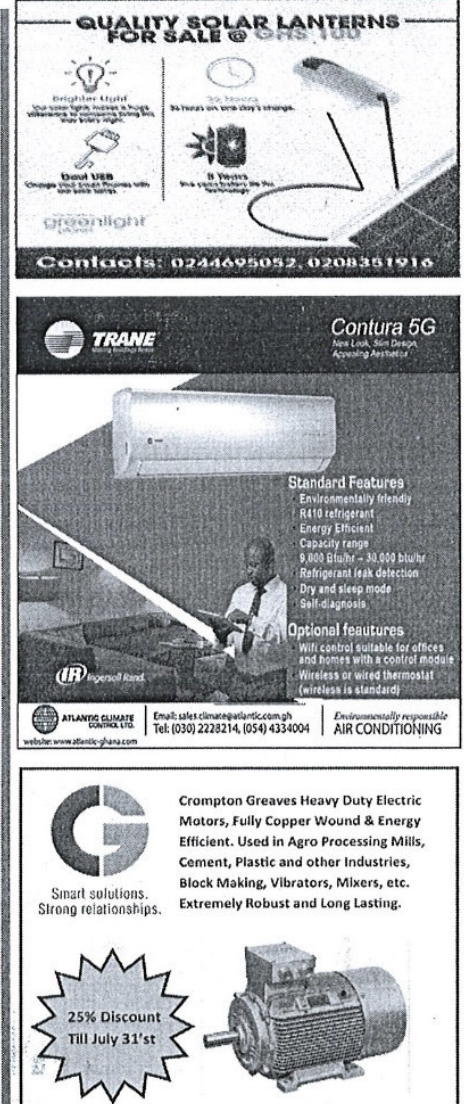

Kay Gee Enterprises City Car potk Building
Opp, stonchart Bank
High Street, Accro

Tel: 0302677518

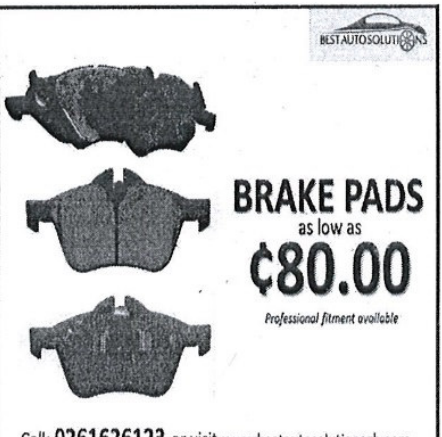

Call: 0261626123 or visit www. bestautosolutionsgh.com

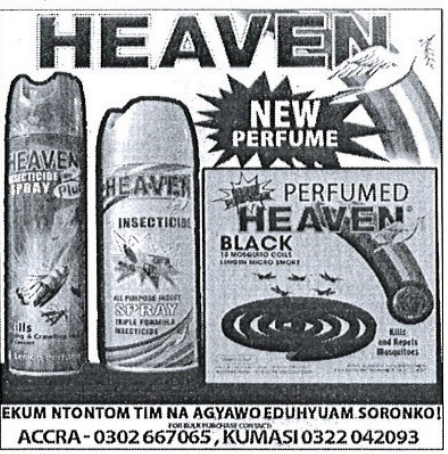




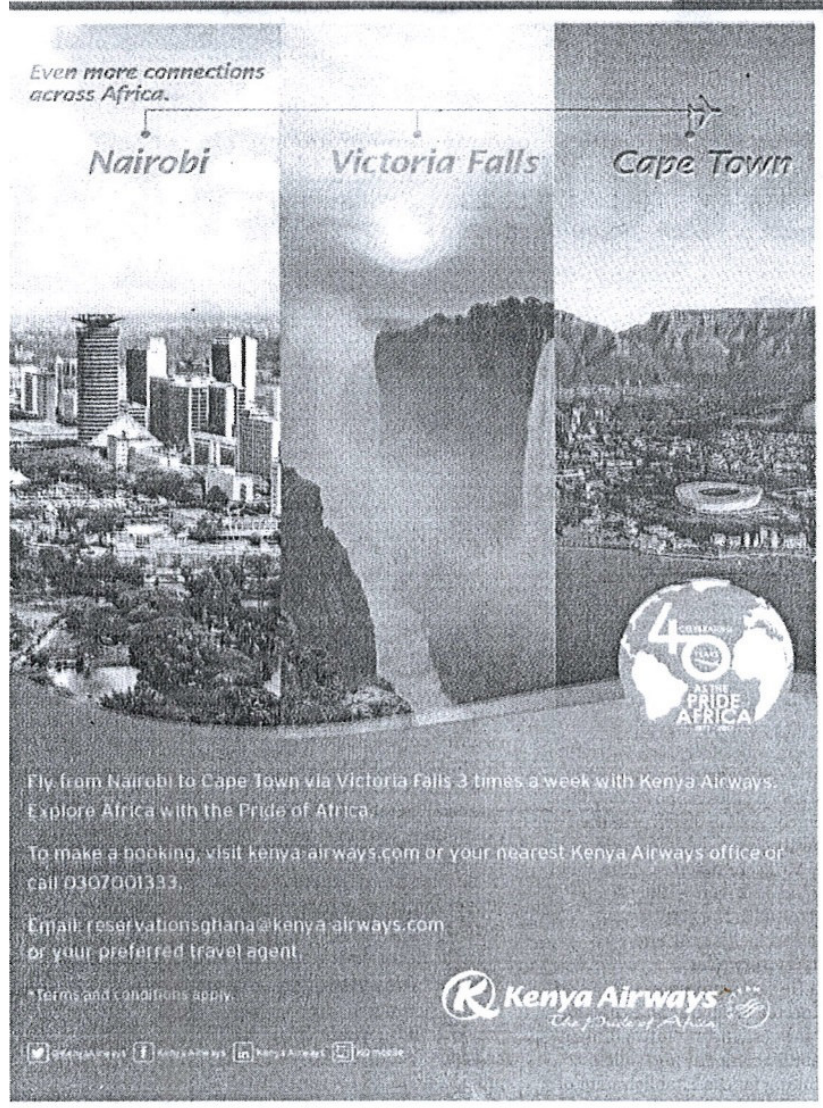

\section{GCB BANK LTD. NOTICE TO SHAREHOLDERS}

Notice is hereby given that in accordance with a communique from the Ghana Stock Exchange (GSE) dated $4^{\text {th }}$ February, 2016 followed by our notification at our last Annual General Meeting (AGM) on 270 My, 206 fonies Act Reports of GCB Bank Limited will henceforth be made avaitacte

1. The full version of the documents listed below shall be published in a widely circulating newspaper, upon prior notice to the shareholders of the date of publication and the newspaper in question.

- Statement of Comprehensive income

Statement of Financial Position

Statement of Cash flows

Director's Report

Auditors Report

2. The Full electronic version of the Annual Report and Financial Statement shall be posted on the website of the Bank as follows:

www.gcbbank.com.gh

3. A limited number of hard copies of the Annual Report shall be made available to shareholders at the grounds of the AGM for use by shareholders attending the meeting.

4. Shareholders who provide their email addresses to the Registrar, GCB Share Registry or to their License Dealing Members (LDM) of GSE/ Central Securities Depository (CSD) will have their Annual Report sent to them via their respective email addresses.

SIGNED:

Helen Addo (Mrs.)

Company Secretary

GCB

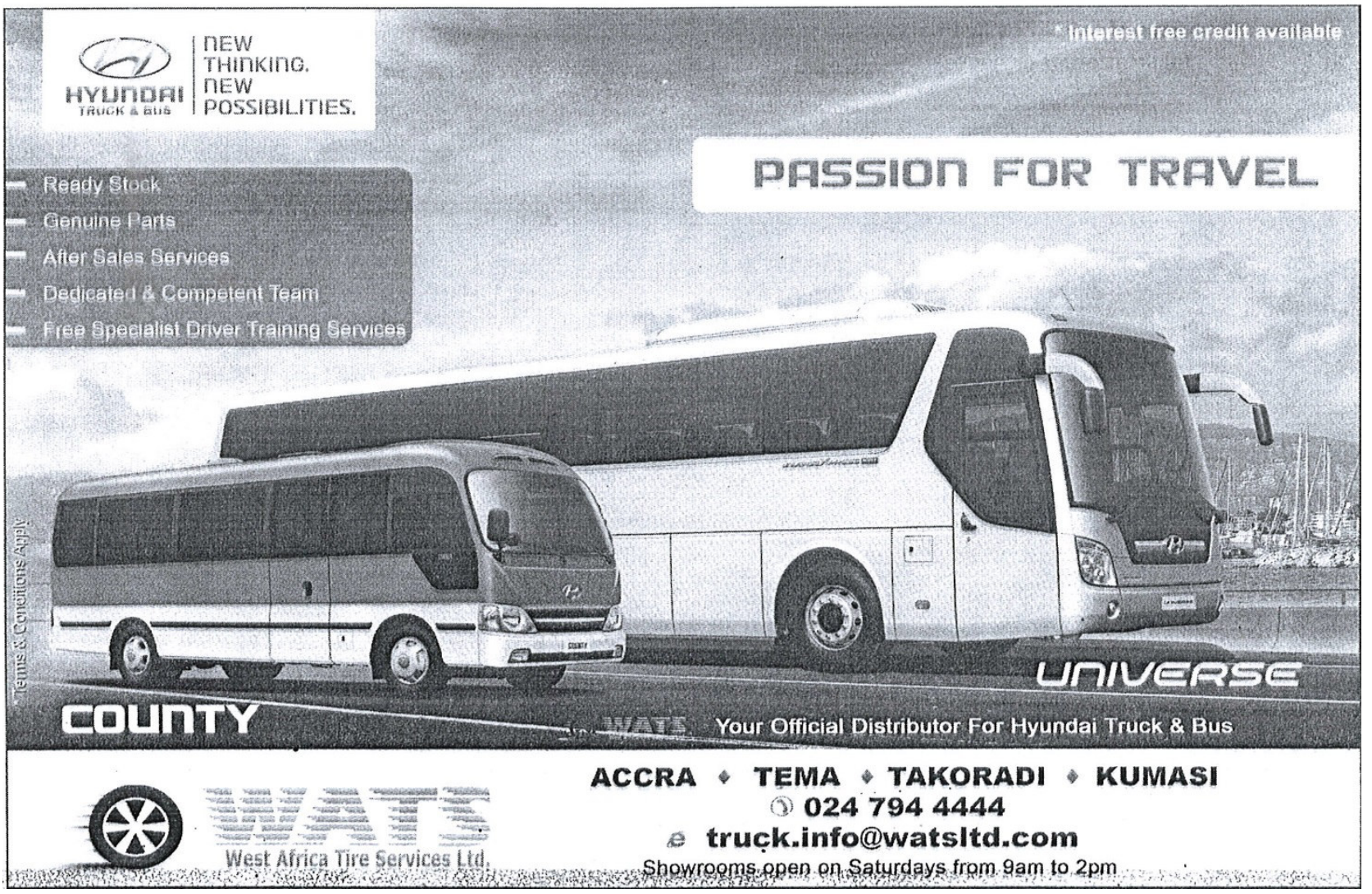

